\title{
Aseptic necrosis of the maxilla on embolized patient: a challenger condition
}

\author{
Anderson Maikon de Souza Santos ${ }^{1} \wedge$, Stéfany Barbosa ${ }^{1 \wedge}$, Tiburtino J. Lima-Neto ${ }^{1}$, Isadora Martins-Silva ${ }^{1}$, \\ Natália Lins de Souza Villarim ${ }^{2} \wedge$, Sirius Dan Inaoka ${ }^{2} \wedge$, Davi Felipe Neves Costa $^{2} \wedge$, Leonardo Perez Faverani ${ }^{1 \wedge}$ \\ ${ }^{1}$ Department of Diagnosis and Surgery, Araçatuba Dental School, Sao Paulo State University (UNESP), Araçatuba, Sao Paulo, Brazil; ${ }^{2}$ Department \\ of Oral and Maxillofacial Surgery, Lauro Wanderley University Hospital, Paraiba Federal University, João Pessoa, Paraíba, Brazil \\ Correspondence to: Anderson Maikon de Souza Santos. Oral and Maxillofacial Surgery, Department of Diagnosis and Surgery, Araçatuba Dental \\ School, Sao Paulo State University (UNESP), Araçatuba, Sao Paulo, Brazil. Email: andersonmaikon@hotmail.com.
}

Received: 16 July 2020; Accepted: 18 October 2020; Published: 20 November 2020.

doi: $10.21037 /$ fomm-20-39

View this article at: http://dx.doi.org/10.21037/fomm-20-39

Aseptic maxillary necrosis is a complication that occurs when there is a reduction or interruption of vascularization in a given region, resulting in the loss of the affected tissues, which may involve only soft or hard tissues. This complication is not caused by an infectious agent, and the vascular supply can be interrupted by factors such as trauma (surgical or not surgical), medication use, radiation and arterial embolization (1-3).

Its occurrence ends up leading to an aesthetic and masticatory deficiency, especially in the case of young patients like the one in this report, who, at the age of 17 , presented aseptic necrosis of the maxilla after osteotomy to remove a nasopharynx tumor. Because it is a patient in good general state of health and a non-smoker, it was hypothesized that the occurrence of this complication is associated to the surgical trauma and the performance of embolization of the maxillary arteries prior to surgery.

Arterial embolization is a procedure where biocompatible materials are arranged in such a way as to occlude arteries or arterioles, which can be performed for different purposes, such as causing tumor necrosis, stopping a hemorrhage, treating pseudoaneurysm or even facilitating the surgical removal of hypervascularized tumors (4), which was the purpose of its use in the present report. The material used to embolization in the present case was microparticles, but there are other options as acrylic adhesive and gelling solutions. Therefore, the decision is according to the clinical application and the expected effect $(5,6)$.

Given the need for removal of a benign tumor located in the nasopharynx, the patient underwent bilateral maxillary artery embolization the day before resection surgery. In the immediate postoperative period, a slight ischemia was observed in the anterior region of the maxilla, which progressed, and at 6 months of follow-up, an extensive necrotic area in the anterior region of the maxilla was seen, involving mucosa, teeth, alveolar process and anterior portion of the hard palate (Figure 1). There were no signs of improvement even after adjuvant therapy with low-power laser (with red, continuous wavelength, power of 5 and $\left.150 \mathrm{~mW} / \mathrm{cm}^{2}\right)$ and Tocopherol ${ }^{\circledR}$ prescription.

Although embolization is associated with cases of skin necrosis, amaurosis, peripheral facial paralysis and necrosis of the oral mucosa, maxillary necrosis after maxillary artery embolization has been little reported $(7,8)$. The rarity of this occurrence is probably related to the rich vascular supply of the anterior region in the maxilla and palate, which is guaranteed by the branches of the external carotid artery (2). However, some vascular conditions were correlated with the risk of occurrence of aseptic necrosis when maxillary artery embolization, of which smoking, diabetes and

^ ORCID: Anderson Maikon de Souza Santos: 0000-0001-9371-9417; Stéfany Barbosa: 0000-0002-4190-7931; Tiburtino J. Lima-Neto: 0000-00028297-4057; Natália Lins de Souza Villarim: 0000-0002-8424-383X; Sirius Dan Inaoka: 0000-0001-9777-347X; Davi Felipe Neves Costa: 0000-00033458-9696; Leonardo Perez Faverani: 0000-0003-2249-3048. 

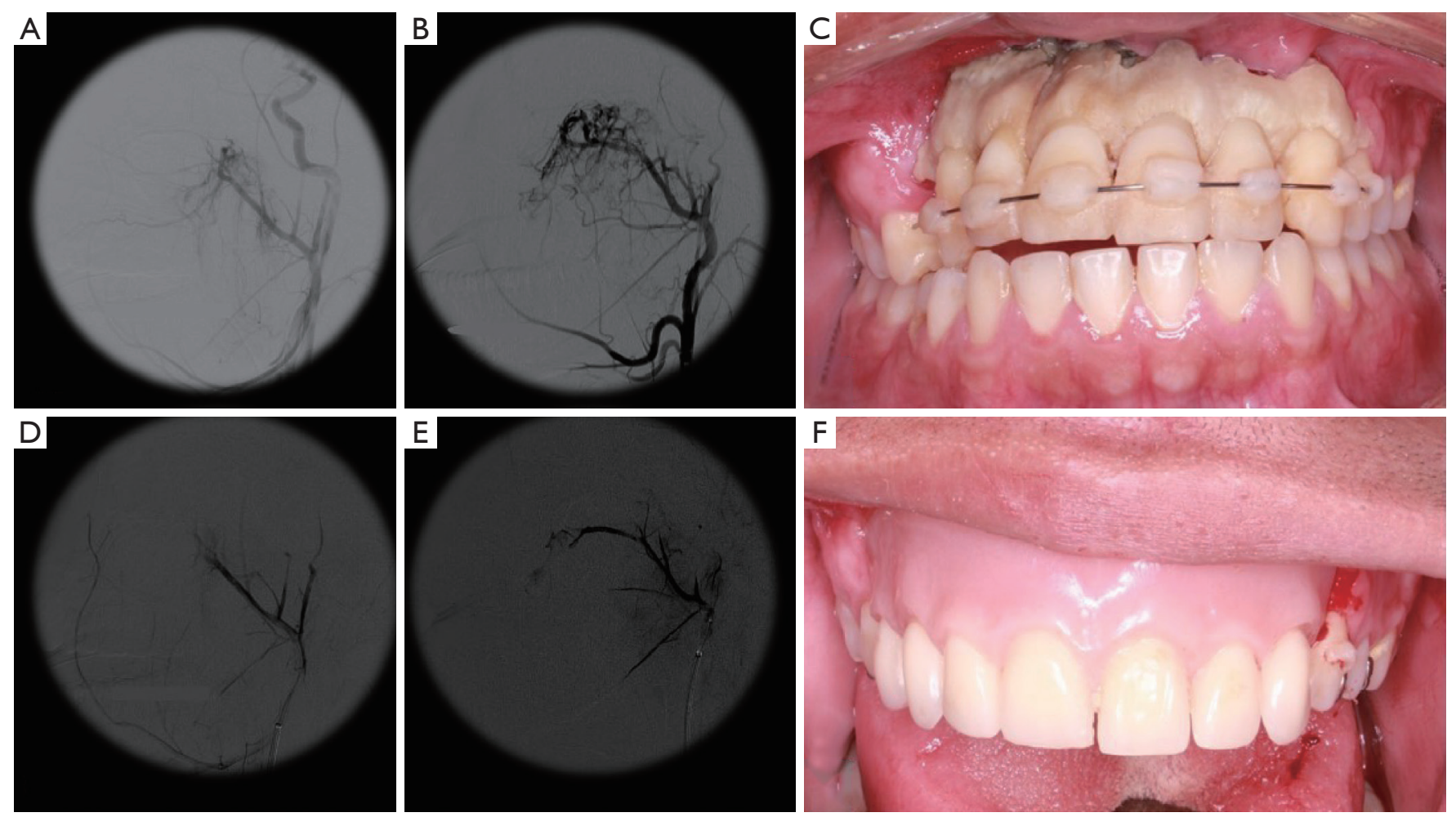

Figure 1 Angiography of the right (A) and left (B) external carotid arteries before embolization. Necrotic area between canines, with involvement of the alveolar process (C). Right (D) and left (E) angiography after embolization, showing reduced vascularization in the region of the maxillary arteries. Immediate rehabilitation with removable prosthesis $(\mathrm{F})$.

poor oral hygiene can be cited (8), which differs from what was observed in this case, where such complication reached a patient who did not have these risk factors. Some precautions during embolization may reduce the chances of this complication occurring, it is important to use thin microcatheters, not to perform forced injection of particles, avoid branches with potentially dangerous anastomoses and pay attention to the size of the selected particle (7).

Besides embolization, another important factor is the management of the tissues during surgery, because improper handling can rupture the vessels responsible for the remaining vascular supply, as well as causing excessive injury, which will hinder the repair. Tumor lesions, such as those in the present case, are often treated more aggressively and can cause major damage to adjacent tissues (9).

Complementary therapies, such as low-level laser therapy and administration of vitamin $\mathrm{E}\left(\right.$ Tocopherol $^{\circledR}$ ), have demonstrated the potential to assist in tissue repair, as both optimize angiogenesis and osteogenesis. However, as seen in the present case, these auxiliary therapeutic modalities are not always sufficient to superimpose tissue damage in conditions of critical vascular decrease, such as that which may occur after the complication of an embolization $(10,11)$.

Once this complication was present, as a therapeutic measure it was decided to resect the entire necrotic area, including the teeth and a fixation miniplate, located in the canine pillar region, which was compromised. We opted for the use of a piezoelectric, considering that this type of surgical instrument reduces the occurrence of damage to adjacent tissues, such as nerve damage, in addition to reduce postoperative edema and providing a more precise and well defined cut compared to conventional saws (12). This was followed by the patient's prosthetic rehabilitation, using a removable prosthesis.

It is concluded that, despite being little reported, aseptic necrosis of the maxilla can occur in conditions of injury to the associated vascular system, requiring embolization procedures to be well indicated and performed. In addition, the need for care during tissue manipulation in surgeries is reinforced, especially in those areas with reduced vascular 
support by embolization.

\section{Acknowledgments}

Funding: None.

\section{Footnote}

Provenance and Peer Review: This article was a standard submission to the journal. The article has undergone external peer review.

Conflicts of Interest: All authors have completed the ICMJE uniform disclosure form (available at https://fomm. amegroups.com/article/view/10.21037/fomm-20-39/coif). LPF serves as an unpaid editorial board member of Frontiers of Oral and Maxillofacial Medicine from Aug 2019 to Jul 2021. The other authors have no conflicts of interest to declare.

Ethical Statement: The authors are accountable for all aspects of the work in ensuring that questions related to the accuracy or integrity of any part of the work are appropriately investigated and resolved. All procedures performed in studies involving human participant were in accordance with the ethical standards of the institutional and national research committees and with the Helsinki Declaration (as revised in 2013). Written informed consent was obtained from the patient.

Open Access Statement: This is an Open Access article distributed in accordance with the Creative Commons Attribution-NonCommercial-NoDerivs 4.0 International License (CC BY-NC-ND 4.0), which permits the noncommercial replication and distribution of the article with the strict proviso that no changes or edits are made and the original work is properly cited (including links to both the formal publication through the relevant DOI and the license). See: https://creativecommons.org/licenses/by-nc-nd/4.0/.

\section{References}

1. Khan N, Memon W, Idris M, et al. Post-traumatic nearcomplete aseptic necrosis of the maxilla: a case report and review of the literature. Dentomaxillofac Radiol 2012;41:429-31.
2. Alalawi WA, Almajed E. Unilateral hard palate necrosis after ascending palatine artery embolization. J Craniofac Surg 2018;29:e437-8.

3. Nastro E, Allegra A, Oteri G, et al. Avascular necrosis of bone in leukemia and osteonecrosis of jaw by bisphosphonates. J Oral Maxillofac Surg 2009;67:2701-3.

4. Neto TJL, Maranhão CAA, Neto PJO. Pseudoaneurysm of facial artery after orthognathic surgery. J Craniofac Surg 2019;30:e607-9.

5. Laurent A, Moine L. The new biomaterials of embolization: the shift to degradable. Med Sci (Paris) 2017;33:25-31.

6. Granata F, Mormina E, Cinquegrani A, et al. Different embolization approaches for the treatment of posttraumatic pseudoaneurysm of the internal maxillary artery. J Craniofac Surg 2018;29:e779-81.

7. Guss J, Cohen MA, Mirza N. Hard palate necrosis after bilateral internal maxillary artery embolization for epistaxis. Laryngoscope 2007;117:1683-4.

8. Nishimoto K, Minoda R, Yoshida R, et al. A case of periodontal necrosis following embolization of maxillary artery for epistaxis. Case Rep Otolaryngol 2016;2016:6467974.

9. Rossell-Perry P. Flap Necrosis after palatoplasty in patients with cleft palate. Biomed Res Int 2015;2015:516375.

10. Akçay H, Kuru K, Tatar B, et al. Vitamin E promotes bone formation in a distraction osteogenesis model. J Craniofac Surg 2019;30:2315-8.

11. Latifyan S, Genot MT, Klastersky J. Bisphosphonaterelated osteonecrosis of the jaw: a review of the potential efficacy of low-level laser therapy. Support Care Cancer 2016;24:3687-93.

12. Silva LF, Carvalho-Reis ENR, Bonardi JP, et al. Comparison between piezoelectric surgery and conventional saw in sagittal split osteotomies: a systematic review. Int J Oral Maxillofac Surg 2017;46:1000-6.

doi: 10.21037/fomm-20-39

Cite this article as: Santos AMS, Barbosa S, Lima-Neto TJ, Martins-Silva I, Villarim NLS, Inaoka SD, Costa DFN, Faverani LP. Aseptic necrosis of the maxilla on embolized patient: a challenger condition. Front Oral Maxillofac Med 2020;2:28. 